\title{
キャパシタ電圧を平衡化した単相倍電圧整流器の特性
}

$\begin{array}{llllll}\text { 正員 } & \text { 清 } & \text { 武 } & \text { 博 } & \text { 文 } & \text { (大分高專) } \\ \text { 正員 岡 } & \text { 田 } & \text { 英 } & \text { 彦 } & \text { (大分 大) } \\ \text { 正員 } & \text { 石 } & \text { 坂 } & \text { 耕 } & \text { 一 } & \text { (福岡 大) } \\ \text { 正員 伊 } & \text { 藤 } & \text { 良 } & \text { 三 } & \text { (福 岡 大) }\end{array}$

\section{Characteristics of Single-Phase Voltage-Doubler Rectifier with Balanced} Capacitor Voltages

Hirofumi Kiyotake, Member (Oita National College of Technology), Hidehiko Okada, Member (Oita University), Kouichi Ishizaka, Member, Ryozo Itoh, Member (Fukuoka University)

A single-phase voltage-doubler rectifier, which has two auxiliary bidirectional switches, is studied. The proposed rectifier has the advantages that the imbalance of the voltages across the capacitors, connected in series, is minimized independent of the working conditions and the discharge of capacitors is adjusted by arranging two auxiliary bidirectional switches. Therefore, the total capacitance of the rectifier can be reduced. The tested setup, using four insulated-gate bipolar transistors (IGBTs) and a microcomputer as a PI controller, is implemented and IGBTs are switched with $20 \mathrm{kHz}$, which is out of audible band. Moreover, a rigorous state-space analysis is introduced to predict the operation of the rectifier. From the results, the well-balanced capacitor voltages can be achieved and the input current can be sinusoidally waveshaped with a near-unity power factor under the steady state and transient conditions even if the rectifier is operated with small seriesconnected capacitors. Consequently, the single-phase voltage-doubler rectifier studied is suitable for AC-DC conversion equipment with output voltage higher than twice that of the supply and with reduced total capacitance.

キーワード : 単相整流器, 倍電圧, キャパシ夕電圧の平衡化, 正弦波入力電流, IGBT

\section{1. まえがき}

ハーフプリッジ構成のスイッチモード単相倍電圧整流器 は簡単な回路構成で倍電圧出力が得られる(1) (2)。この整 流器はパワーフローが可逆である。出力端に直列接続され たキャパシタの中性点が利用できる，などの特長を有し， 大きな出力が必要なインバータの電源として使用されてい る。しかしながら，キャパシタの電圧が本質的に不平衡で あるため, 動作条件によってはキャパシタ電圧が電源電圧 のピーク值よりも小さくなり，その結果入力電流の正弦波 化が困難であることが指摘されている(1)。また，ハーフブ リッジタイプのインバータを負荷としたとき，インバータ 入力の中性点電位が変動するのでインバー夕出力波形を歪 ませる原因になる。一方，不必要なキャパシタの放電を調 整するためにダイオードブリッジとスイッチング素子から なる双方向スイッチを付加した回路構成が提案されている が(3), キャパシタ電压の不平衡はほとんど改善されない。 本論文は, 出力端に直列接続されたキャパシタの電圧を
平衡化させるため, 従来の整流器にダイオードブリッジと IGBT からなる 2 個のキャパシタ充放電用双方向スイッチ を付加した単相倍電圧整流器を提案したものであ る(4) (7)。この整流器の特長は, キャパシ夕電圧の平衡化 と放電調整を同時に行う点にあり, 容量の小さなキャパシ タを用いてもキャパシタ電圧を平衡化させることができ る。従って, 出力端に接続するキャパシタ全体の容量を低 減でき，かつ負荷が大きいときにもキャパシタ電圧は十分 に平衡化され，入力電流を正弦波状に制御できることが期 待される。

本論文では，実験並びに状態空間法を用いたシミュレー ションから，定常および過渡状態においてもキャパシタ電 压は十分に平衡化され，注湾力率 1 の正弦波状入力電流が 得られることを明らかにする。

\section{2. 主回路構成}

図1にスイッチモード単相倍電圧整流器の基本構成を示 す(2)。この整流器は, IGBT $Q_{1} ， Q_{2}$ のオンオフ制御によ 
り倍電圧出力が得られると共に, 双方向パワーフローが可 能である。しかし，出力端に直列接続されたキャパシ夕 $C_{p}, C_{n}$ の容量を小さく設定するとキャパシ夕電圧 $e_{p}$ と $e_{n}$ 亿脈動が生じて不平衡となる。これは, 例えば電源電 圧 $v \geqq 0$ のとき， $Q_{2}$ のスイッチングごとに $C_{p}$ は充電, $C_{n}$ は放電を繰り返すためである。負荷が大きくなるに従って この不平衡が顕著になり, 電源電圧のピーク值よりもキャ パシ夕電圧が低下すると昇圧動作の条件を満足できず，入 力電流の正弦波化は困難になる。

一方, 出力端からみた等価キャパシタンスを増加させる ため, 図 1 の整流器にキャパシタ $C_{2}$ を付加した単相倍電 圧整流器を図 2 に示す (1)。C $C_{2}$ は出力電圧 $e_{2}$ の平滑化を担 うため, 出力端に接続されたキャパシ夕全体の容量を低減 することができる。しかし， $C_{1 p}, C_{1 n}$ の容量を小さく設 定すると，依然としてキャパシ夕電圧の不平衡が生じ，負 荷が大きくなって昇圧動作の条件を満足できなくなると入

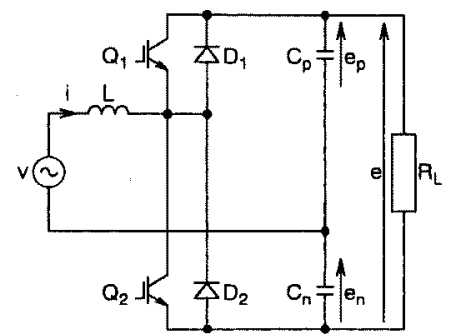

図 1 単相倍電圧整流器の基本構成

Fig. 1. Basic configuration of single-phase voltage -doubler rectifier.

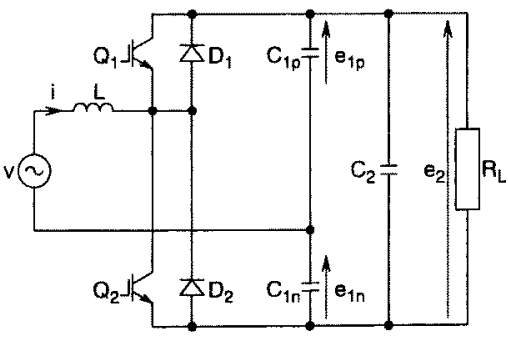

図2 平滑キャパシタを付加した 単相倍電圧整流器

Fig. 2. Single-phase voltage-doubler rectifier with a smoothing capacitor.

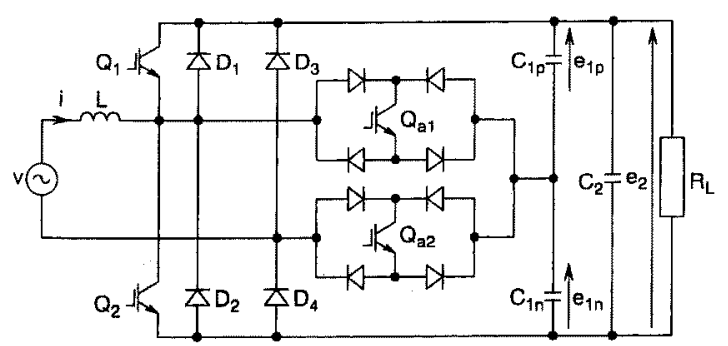

図 3 提案する単相倍電圧整流器

Fig. 3. Proposed single-phase voltage-doubler rectifier.
力電流の正弦波化が困難になる。

図 3 に本論文で提案する単相倍電圧整流器を示す。これ は図 2 の整流器にダイオード $D_{3}, D_{4}$ およびダイオードブ リッジと IGBT $Q_{a 1} ， Q_{a 2}$ で構成されるキャパシ夕充放電 用の双方向スイッチを2 個付加したものである。双方向ス イッチは1スイッチング周期毎にキャパシ夕電圧 $e_{1 p}, e_{1 n}$ の低い方のキャパシタを充電するようにオンオフ制御され る。従って，スイッチング周波数を高く設定することによ つて出力端に接続されたキャパシタ全体の容量を低減しな がらキャパシタ電圧の平衡化が実現できる。

\section{3. 動作原理}

提案する単相倍電圧整流器に前述の動作を行わせるため の制御信号を図 4 に示す。図中の $\left(e_{1 p}-e_{1 n}\right) /\left|e_{1 p}-e_{1 n}\right|$ は $e_{1 p}$ と $e_{1 n}$ の大小関係を表すために用いたものであり， $e_{1 p}>e_{1 n}$ のときは $1, e_{1 p}<e_{1 n}$ のときは一 1 となる。IGBT の制御信号はクロックパルスの立ち上がり，iとiの基準

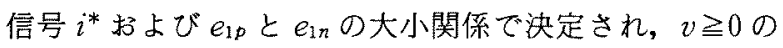
とき, $Q_{2}, Q_{a 2}$ をオン, $Q_{2}$ のみオン, $Q_{a 1}$ のみオン, $Q_{a 2}$ のみオンの 4 通りがある。したがって, 提案する単相倍電 圧整流器の動作は図 5 に示す 5 つの動作モードで表され る。他方, 単相整流器の動作は交流入力の半サイクルを考

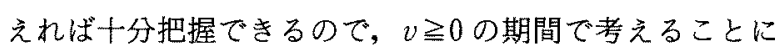
する。

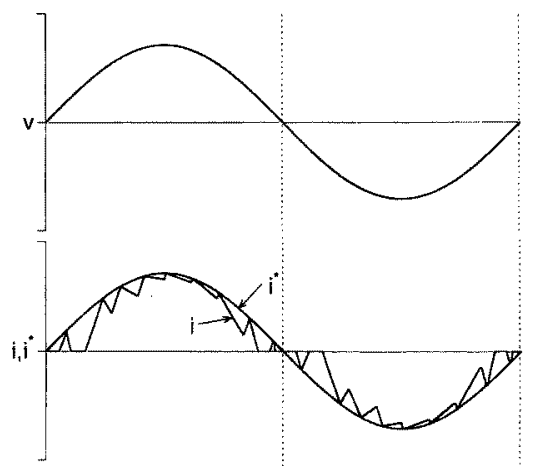

クロックパルх
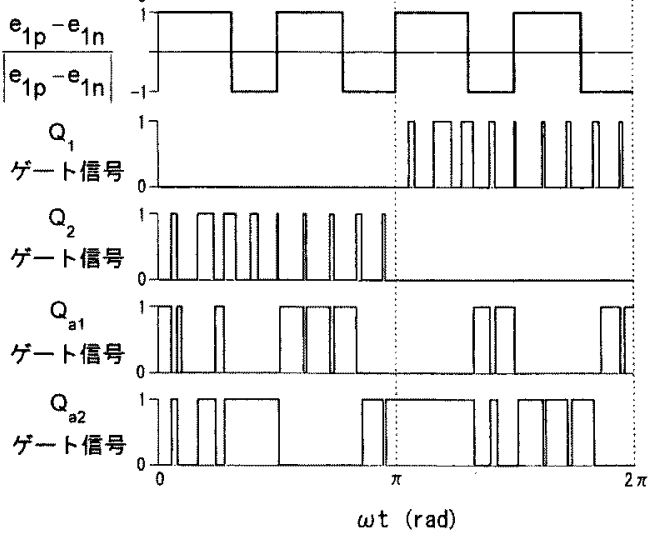

図 4 IGBT の制御信号

Fig. 4. Control signals of IGBTs. 
以下，図 5 に従って各モードの動作を説明するが， $v<$ 0 のときは $Q_{2}$ を $Q_{1}$ に置き換えて考えればよい。

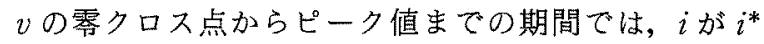
に追従するように，クロックパルスの立ち上がりと同期し てメインスイッチ $Q_{2}$ と同時に補助スイッチ $Q_{a 2}$ をオンす る。このとき図示の極性で充電されていた $C_{1 n}$ が放電し て, $C_{1 n}$ の電圧 $e_{1 n}$ が $v-L-Q_{2}-C_{1 n}-Q_{a 2}$ の経路で $v$ に 重畳され，入力電流 $i$ は $\left(v+e_{1 n}\right) / L$ に比例して上昇する。 このモードを図 5(1)に示す。また, vのピークから次の 零クロス点まではキャパシタの不必要な放電を防ぐため, クロックパルスの立ち上がりと同期して $Q_{2}$ だけをオンす る。したがって, $i$ は $v-L-Q_{2}-D_{4}$ の経路で流れ, $v / L$ に比例して增加する。このときのモードを図5(2)に示 す。

$i$ が基準値 $i^{*}$ に達したとき $Q_{2}$ をオフする。この後の動 作モードはキャパシタ電圧 $e_{1 p}, e_{1 n}$ の大小関係によって電 圧が低い方のキャパシタが充電されるように切り替わる。 すなわち， $e_{1 p}>e_{1 n}$ のときは，図5(3)に示すようにQ $Q_{2}$ オフと同時に $Q_{a 2}$ をオ， $Q_{a 1}$ をンするとv-L-Q $Q_{a 1}$ $-C_{1 n}-D_{4}$ の経路で $C_{1 n}$ が充電される。一方, $e_{1 p}<e_{1 n}$ の ときは, 図 5(4)に示すように, $v$ の零クロス点からピー ク値までは $Q_{a 2}$ のオン状態を保ち, また, $v$ のピークから 次の零クロス点までは $Q_{a 2}$ をンすると $v-L-D_{1}-C_{1 p}$ - $Q_{a 2}$ の経路で $C_{1 p}$ が充電される。図 5(3)，(4)のモー ドでインダクタ $L$ のエルギーが放出し終わると入力電 流は 0 になり, 整流器は図 5(5)に示すモードで動作し, 負荷は電源と切り離される。したがって, $v \geqq 0 の$ 期間に おける動作モードの推移は, $v$ の零タロス点から $\pi / 2$ の期 間では図5(1)と（3）または（1）と（4)を1スイッチング 周期ごとに繰り返し， $\pi / 2$ から次の零クロス点の期間では 図 5(2)と(3)または(2)と(4)を繰り返す。ただし, 図 $5(3)$ ，(4)のモードで $i=0$ になると図 5(5)のモードへ 移行索る。

なお，図 1 および図 2 に示す整流器の動作モードは，そ れぞれ $Q_{2}$ をオンした場合は図 5(1)，Q $Q_{2}$ をオフした場合 は図 5(4), 入力電流が 0 になると図 $5(5)$ に示すモード に相当する。従って, 図 1 抢よび図 2 の整流器では図 5 (2)と (3)に相当するモードは存在せず, キャパシ夕電 圧の平衡化とキャパシタの放電調整が不可能である。

以上の動作を実現させるための電圧・電流制御ブロック 図を図6に示す。まず，予めROMにvと同期した単位 大きさの正弦全波整流信号を書き込んでおき, PI 制御器

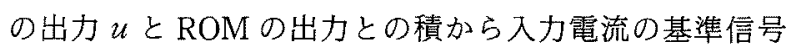
$\left|i^{*}\right|$ を得る。また, メインスイッチ $Q_{1}, Q_{2}$ は可聴帯域外 の $20 \mathrm{kHz}$ のクロックパルスと等しい周波数でオンオフ制 御される。一方, 図示のように単安定マルチバイブレータ 1 および 2 を使って $C_{1 p}$ 抢よび $C_{1 n}$ が放電する期間を電源 電圧の零クロス点功 $\pi / 2$ 範囲に設定している。

次に, $|i|$ が $\left|i^{*}\right|$ に達すると,コンパレータの働きによっ

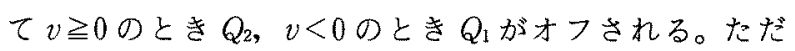

し，前述したように， $Q_{a 2}$ がモードの切り替わる前後にお

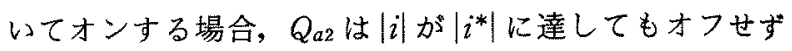
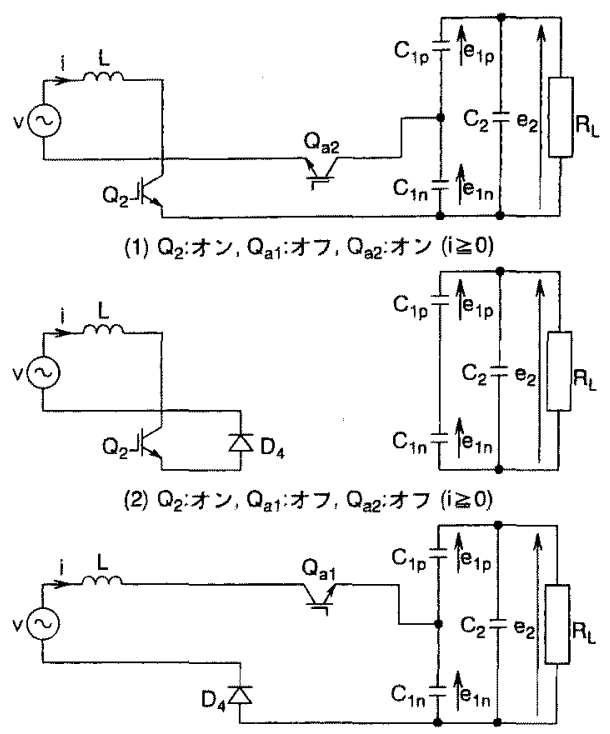

(3) $Q_{2}:$ オフ, $Q_{a 1}:$ オン, $Q_{a 2}:$ オフ (1>0)

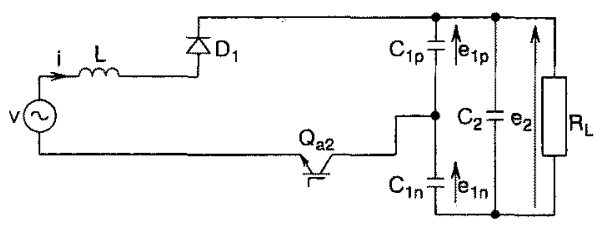

(4) $\mathrm{Q}_{2}:$ オフ, $\mathrm{Q}_{\mathrm{a} 1}$ オフフ, $\mathrm{Q}_{\mathrm{a} 2}:$ オン(i>0)

(5) $\mathrm{Q}_{2}:$ オフ, $\mathrm{Q}_{\mathrm{a} 1}:$ オフ $\mathrm{Q}_{\mathrm{a} 2}:$ オフ $(\mathrm{i}=0)$

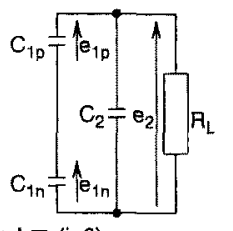

図 5 図 3 の動作モード

Fig. 5. Operating mode of Fig. 3.

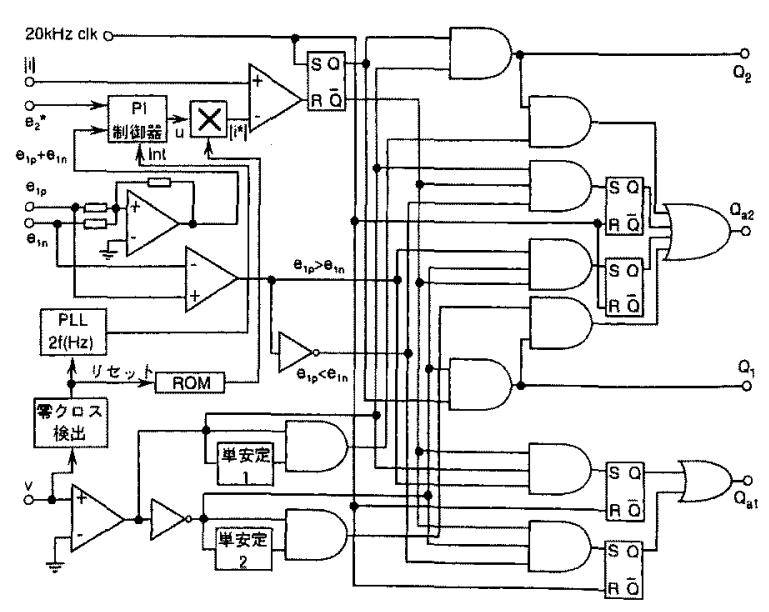

図 6 電圧・電流制御ブロック図

Fig. 6. Voltage and current control block diagram. 
にオン状態を保つ。なお， $e_{1 p}, e_{1 n}$ の大小関係によっては $Q_{a 1}, Q_{a 2}$ のオンオフがクロック周波数の $20 \mathrm{kHz}$ を越えて 高速で切り替わる可能性がある。このような高速スイッチ

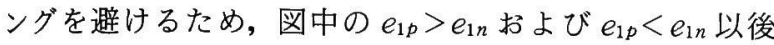
の論理回路で示すように 1 スイッチング周期の間は $Q_{1}$ あ るいは $Q_{2}$ がオフした時点での電圧が低い方のキャパシタ を充電し続けるようにした。

\section{4. 実測 波形}

図 7 および図 8 に, それぞれ図 2 と図 3 に示した整流器 の実測動作波形を示す。ただし，動作条件および回路定数 を $V=50 \mathrm{~V}, f=60 \mathrm{~Hz}, L=2.105 \mathrm{mH}(r=0.112 \Omega), C_{1 p}$ $=C_{1 n}=270 \mu \mathrm{F}, C_{2}=1,000 \mu \mathrm{F}, R_{L}=49.84 \Omega$ とし, 出力

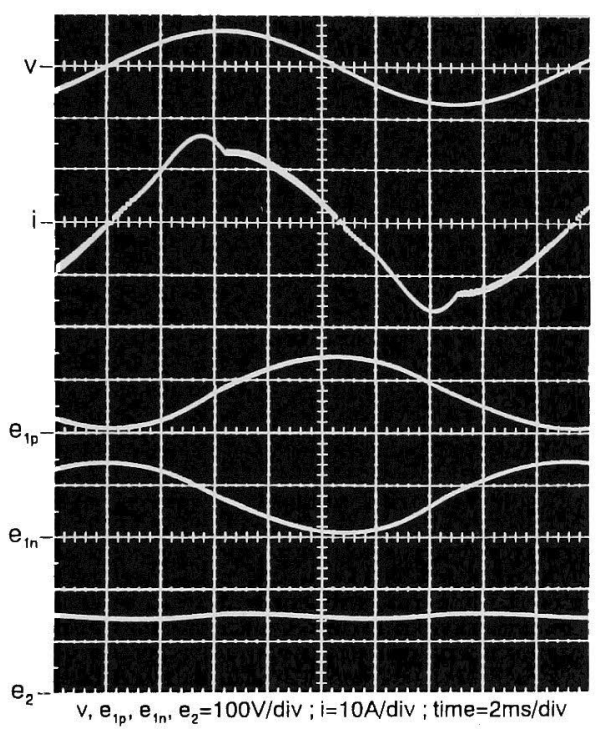

図 7 図 2 の実測波形

Fig. 7. Experimental waveforms of Fig. 2.

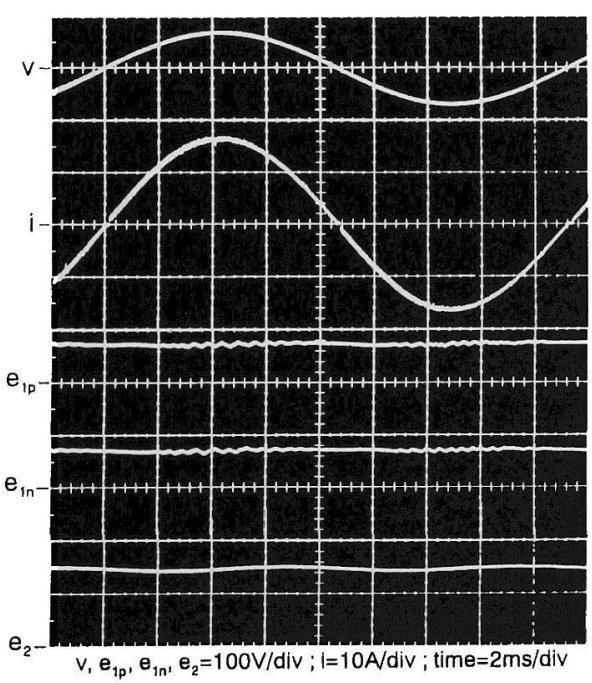

図 8 図 3 の実測波形

Fig. 8. Experimental waveforms of Fig. 3.
電圧 $e_{2}$ の平均值が電源電圧ピーク值の約 2 倍の $150 \mathrm{~V}$ と なるように PI 制御器の出力電圧基準値 $e_{2}$ *を調整した。 また, $r$ はインダクタ $L$ の抵抗, $V$ は電源電圧 $v$ の実効 值である。図 7 より, 図 2 の整流器ではキャパシタ電圧 $e_{1 p}, e_{1 n}$ が電源周波数と等しい周波数で脈動し, その結果 $e_{1 p}$ と $e_{1 n}$ に不平衡が顕著に現れると共に, 入力電流 $i か ゙$

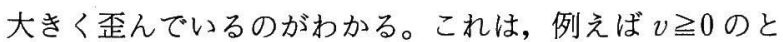
き, $e_{1 p}$ が $v$ よりさくなる所が存在し, 昇圧動作の条件 を満足しないためである。このような現象は, 昇圧比を変 化させても改善されないことを実験によって確認してい る。また, $e_{1 p}$ と $e_{1 n}$ は, それぞれ $v$ が負から正に変化す る付近と正から負に変化する付近で零近くまで低下してい る。負荷をさらに大きくするとキャパシ夕電圧の不平衡は 一層顕著になり，その結果 $e_{1 p}, e_{1 n}$ の極性が反転する。一 方, 図 8 では $e_{1 p}, e_{1 n}$ はそれぞれ $e_{2} / 2$ にほとんど等しく, かつ十分に平衡化して抒り，入力電流 $i$ はほぼ力率 1 で正 弦波状に制御されていることがわかる。

図 7 と図 8 に示した入力電流の波形歪みの主な原因とな る低次高調波成分の基本波に対する割合を表 1 に示す。た

表 1 入力電流の低次高調波成分

Table 1. Low order harmonic contents of input currents.

\begin{tabular}{c|c|c}
\hline 高調波次数 & \multicolumn{2}{|c}{$\mathrm{a}_{\mathrm{h}} / \mathrm{a}_{1}(\%)$} \\
\hline $\mathrm{h}$ & 図 7 & 図 8 \\
\hline 3 & 9.294 & 0.675 \\
\hline 5 & 5.594 & 0.107 \\
\hline 7 & 2.924 & 0.106 \\
\hline 9 & 1.044 & 0.142 \\
\hline 11 & 0.951 & 0.158 \\
\hline 13 & 0.438 & 0.120 \\
\hline 15 & 0.447 & 0.152 \\
\hline 17 & 0.400 & 0.119 \\
\hline 19 & 0.178 & 0.137 \\
\hline
\end{tabular}

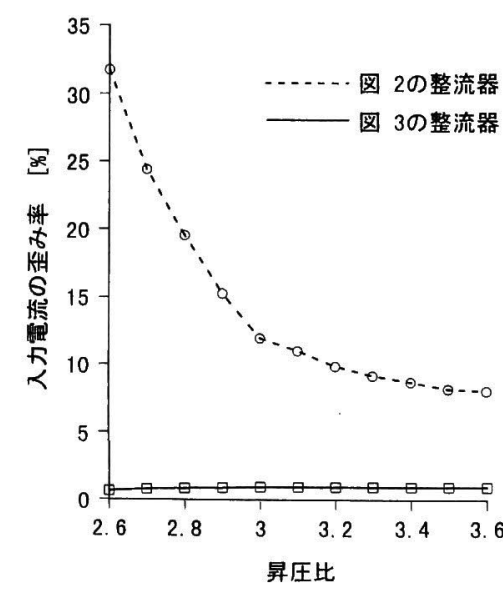

図 9 昇圧比に対する歪み率

Fig. 9. Distortion factor for step-up ratio. 
だし，表 1 は電源と直列に $0.1 \Omega$ の検出用抵抗を接続し， その端子電圧を FFT アナライザによって分析した結果で ある。また， $a_{h}$ は第 $h$ 次高調波電流の大きさである。同 表より，図 3 に示した提案する整流器では低次高調波成分 はいずれも $0.7 \%$ 以下と十分抑制されていることがわか る。ちなみに, 図7の場合の入力電流の実測歪み率

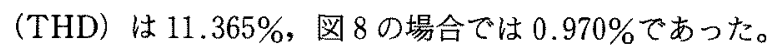

図 2 と図 3 の整流器で昇圧比を変化させた場合の入力電 流の実測歪み率を図 9 に示す。ただし, 昇圧比は $e_{2}$ の平 均值を $E_{2}$ としたとき， $E_{2} / V$ で定義した。図 9 から，図 2 の整流器では昇圧比を大きくしても入力電流の歪み率を 大幅に改善することはできないが，提案する整流器では図 示の昇圧比の範囲で $1.0 \%$ 以下であり，ほほ一定であるこ とがわかる。

\section{5. シミュレーション}

前述のように, 単相整流器の動作は交流入力の半サイク ルを考えれば十分把握できるので，シミュレーションは $v \geqq 0$ 半周期を考えることにする。

電源電圧は, 実効値を $V$ とすると次式で表される。

$$
v=\sqrt{2} V \sin \omega t
$$

一方, 煩雑な畳み远み積分を用いないで状態方程式を解く ために

$$
v_{f}=\sqrt{2} V \cos \omega t
$$

で表される仮想電圧 $v_{f}$ を考えると，

$$
\begin{aligned}
& \frac{d v}{d t}=\omega v_{f} \\
& \frac{d v_{f}}{d t}=-\omega v
\end{aligned}
$$

である。また, $e_{2}$ は

$$
e_{2}=e_{1 p}+e_{1 n}
$$

で与えられるので, 状態変数 $x$ を

$$
x=\left[v, v_{f}, i, e_{1 p}, e_{1 n}\right]^{T}
$$

のように定義したとき, 各モードの回路方程式から導出さ れた定数係数行列 $A$ を用いて,

$$
\frac{d x}{d t}=A x
$$

の形式の状態方程式が得られる。ただし，(6) 式右肩添字 $T$ はべクトルの転置を示すものとする。時刻 $t$ における $x$ を $x(t)$, 微少時間を $\Delta t$ としたとき, $x(t+\Delta t)$ は, (7) 式から

$$
\boldsymbol{x}(t+\Delta t)=e^{A \Delta t} \boldsymbol{x}(t)
$$

によって計算できるので，シミュレーションは（７)式で表 される図 5(1)から(5)までの各動作モードの状態方程式 と PI 制御則を組み合わせて出力電圧が所望の基準值 $e_{2}{ }^{*}$ に収束するまで, 動作モードを判別しながら（8)式の計算 を繰り返して行った。本論文では，スイッチング周波数を 考慮して $\Delta t=(\pi / \omega) / 18,000 \fallingdotseq 0.463 \mu \mathrm{s}$ とした。

図 7,80実測波形と同じ動作条件，同じ回路定数の下 でのシミュレーション結果をそれぞれ図 10，11に示す。

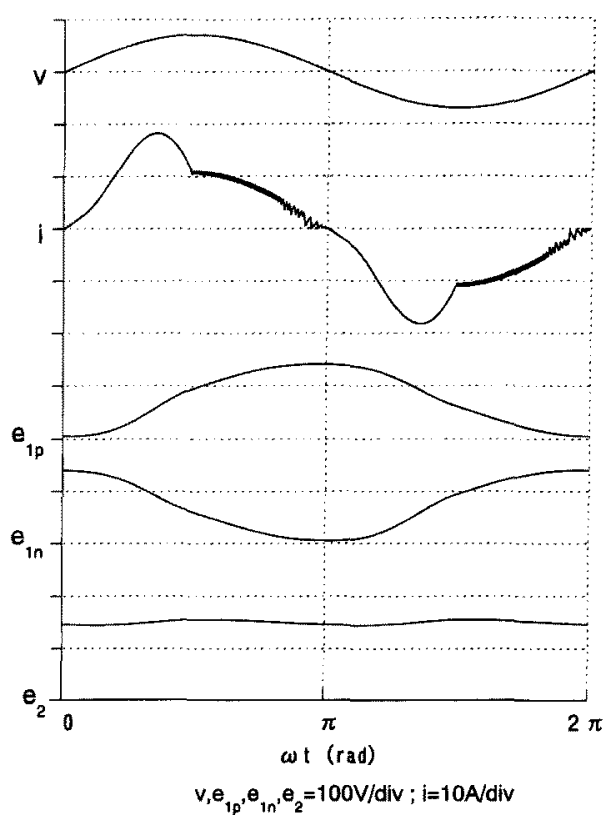

図 10 図 7 のシミュレーション結果

Fig. 10. Simulated results of Fig. 7 .

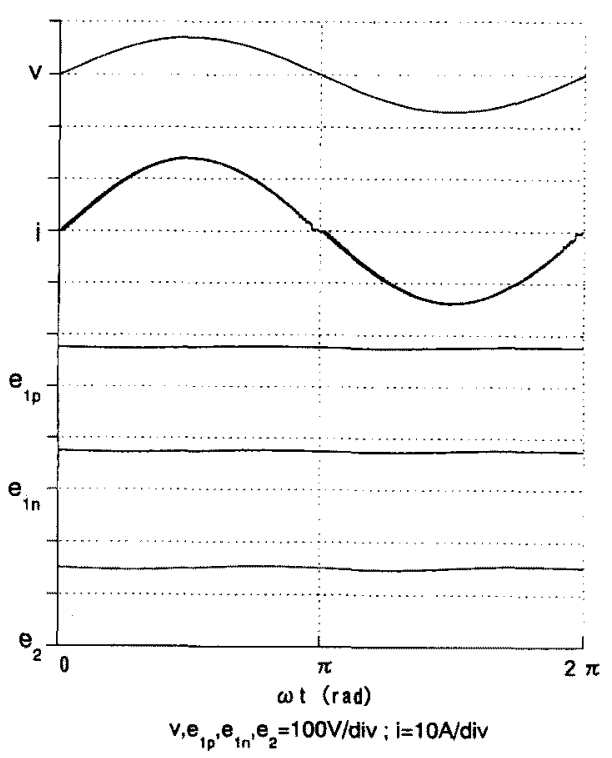

図 11 図 8 のシュレーション結果

Fig. 11. Simulated results of Fig. 8 .

シミュレーション結果は，実測波形とほほ一致している が，入力電流の大きさに若干の差が見られる。これはシミ ュレーションでは無視した素子の電圧降下, スイッチング 損失，インダクタの鉄損などが影響しているものと考えら れる。なお，図 2 の整流器で提案する整流器と同程度のキ ヤパシタ電圧の平衡化を行うには, $C_{1 p}, C_{1 n}$ として, 約 $10^{4} \mu \mathrm{F}$ 程度の大きな容量のキャパシタが必要であることを 確認している。 


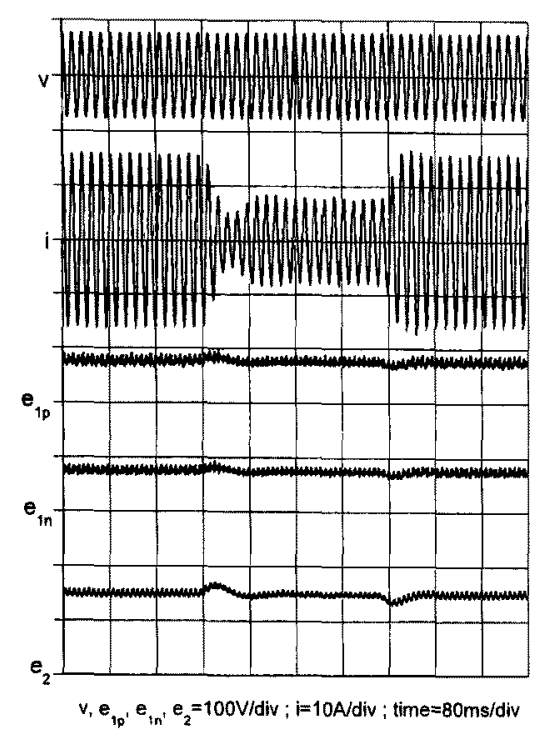

図 12 負荷変化時の実測過渡応答 Fig. 12. Experimental transient responses when changing the load.

\section{6. 過渡特性}

提案する倍電圧整流器の過渡特性を検討するために, 負 荷変化時の実験とシミュレーションを行った。なお, 本論 文では PI 制御則として

$$
\begin{aligned}
u(n T)= & u\{(n-1) T\}+k_{p}[\varepsilon(n T)-\varepsilon\{(n-1) T\}] \\
& +k_{i} \varepsilon(n T) \cdots \ldots \ldots \ldots \ldots \ldots \ldots \ldots \ldots \ldots \ldots \ldots \ldots \ldots \ldots \ldots \ldots \ldots
\end{aligned}
$$

を用いた。ただし， $k_{p} ， k_{i}$ はそれぞれ比例，積分の各ゲイ ン, $n$ は正の整数， $T$ は $1 / 2 f$ に等しいサンプリング周期 であり, $e_{2}(n T)$ を $t=n T$ における出力電圧の検出值と したとき, $\varepsilon(n T)=e_{2}{ }^{*}-e_{2}(n T)$ である。また，(9)式の 計算はマイクロコンピュータを用いて行った。

今, $k_{p}=0.21, k_{i}=0.12$ に設定し, $e_{2}{ }^{*}=150 \mathrm{~V}$ の条件 下で負荷抵抗 $R_{L}$ を $49.84 \Omega$ から $99.68 \Omega$ 八, さらに $49.84 \Omega$ へと変化させたときの実験による過渡応答を図 12,シミュレーション結果を図 13 に示す。

両図より, 実験結果はシミュレーション結果とほほ一致 しており，過渡状態に括いてもキャパシタ電王が十分に平 衡化され, 卧为率 1 の正弦波入力電流が達成されている ことがわかる。

\section{7.あとがき}

以上，キャパシタ充放電用の双方向スイッチを付加した 単相倍電圧整流器を提案し, 試作装置による実験および状 態空間法によるシミュレーションを行った。その結果, 出 力端に直列接続されたキャパシタを小さく設定してもキャ パシ夕電圧は十分に平衡化され入力電流をほほ力率 1 で正 弦波状に制御できることを明らかにした。提案した単相倍

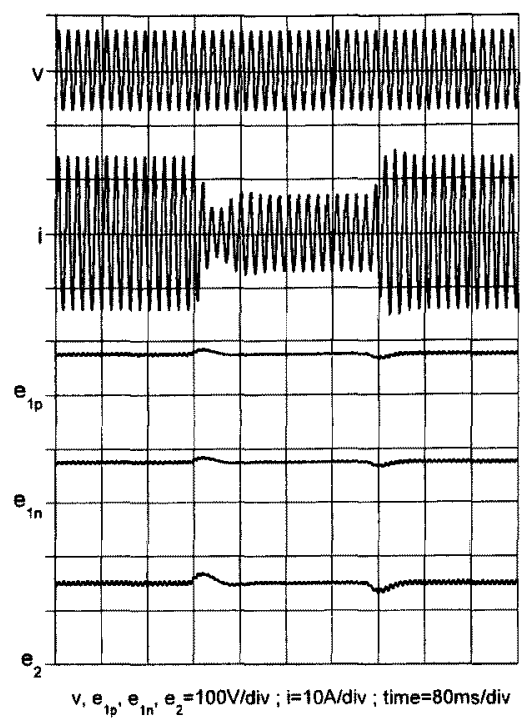

図 13 負荷変化時の解析過渡底答 Fig. 13. Simulated transient responses when changing the load.

電圧整流器は, キャパシタ電圧の平衡化と放電調整を同時 に行える点に特長があり，出力端に接続するキャパシタ全 体の容量を低減することができる。キャパシタ電圧の平衡 化は, キャパシタの接続点いわゆる中性点の電位変動を小 さくし，例えば単相ハーフブリッジインバータのように中 性点を利用するインバー夕の電源回路として有用であると 考えられる。

最後に, 本研究の実験に協力された福岡大学大学院工学 研究科博士課程前期学生竹川剛義君に謝意を表します。

(平成 12 年 11 月 30 日受付, 同 13 年 5 月 2 日再受付)

\section{文献}

（1）牧野・田村・牛嶋・塚本：「双方向電流制御形コンバー夕による 空調機の新電源方式」, 昭 63 電気学会麾業応用部門全大, No. 98

(2) J. T. Boys and A.W. Green: "Current-Forced Single-Phase Reversible Rectifier", IEE Proc. B, Electr. Power Appl., 136, No. 5, 205 211 (1989)

(3) J.C. Salmon: "Circuit Topologies for Single-Phase VoltageDoubler Boost Rectifiers", IEEE Trans, Power Electro., PE8, No. 4, 521 $\sim 529$ (1993)

(4) H. Kiyotake, H. Okada, K. Ishizaka, and R. Itoh: "SinglePhase Voltage-Doubler Rectifier with Balanced Capacitor Voltages", PCIM INTER '98 JAPAN, 289 294 (1998)

（5）清武・岡田・石坂・伊藤：「キャパシ名電圧を平衡化した単相倍 電压整流器」, 電学論 D, 118, No. 4, 552 553 (平 10)

（6）清武・网田・石坂・伊藤：「キャパシ夕電压を平衡化した単相倍 電压整流器の回路構成了, 平 10 電気学会半導体電力変換研資, $\mathrm{SPC}-98-98$

(7) H. Kiyotake, H. Okada, K. Ishizaka, and R. Itoh: "SinglePhase Voltage-Doubler Boost Rectifier Minimizing the Im balance of Capacitor Voltages", IPEC-Tokyo 2000, 2, 862 $867(2000)$ 
清 武 博 文（正員） 1964 年 9 月 23 日生。90 年 3 月鹿児島 大学大学院工学研究科電気工学専攻修士課程修 了。同年 4 月 (株) 東芝・医用機器技術研究所, 96 年 4 月大分工業高等専門学校講師, 99 年 10 月同助教授, 現在に至る。パワーエレクトロニ クスに関する研究に従事。

岡田英彦 (正員) 1940 年 3 月 20 日生。6 8 年 3 月九州大 学大学院工学研究科電気工学専攻博士課程修了。 同年 4 月同大工学部講師, 74 年 4 月大分大学工 学部助教授, 78 年 1 月同教授, 現在に至る。工 学博士。パワーエレクトロニクス, 超電導応用 に関する研究に従事。
石 坂 耕一（正員） 1953 年 11 月 13 日生。 76 年 3 月福岡大

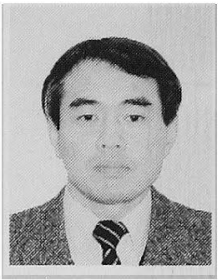
学工学部電気工学科卒業。同年 4 月同大工学部 教育技術職員, 現在に至る。パワーエレクトロ ニクスに関する研究に従事。

伊 藤 良三（正員） 1947 年 10 月 9 日生。 75 年 3 月九州大

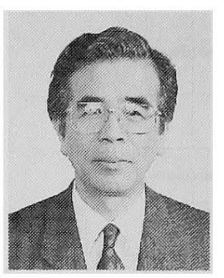
学大学院工学研究科電気工学専攻博士課程修了。 同年 4 月福岡大学工学部講師, 79 年 4 月同助教 授, 88 年 4 月同教授, 現在に至る。工学博士。 パワーエレクトロニクス，超電導応用に関する 研究に従事。 